\title{
SÍNTESIS DE ACTIVIDADES DEL DEPARTAMENTO DE ESPAÑOL DEL INSTITUTO DE TRADUCTOLOGÍA, 2018
}

Durante el año 2018 los miembros del Departamento de Español del Instituto de Traductología de la Facultad de Filosofía y Letras de la Universidad Carolina realizaron las siguientes actividades académicas:

La Prof. PhDr. Jana Králová, CSc. publicó los siguientes artículos: 1) "Versión checa de Brevísima destrucción de las Indias de Bartolomé de Las Casas", en: Antonio Bueno García (ed.), Revelación y traducción en la Orden de Predicadores, Berlín: Petr Lang, pp. 313-324; 2) "K redefinici vybraných pojmů ve španělské translatologii optikou prací Jiřího Levého" [A la redefinición de unos conceptos seleccionados de la traductología española en la óptica de los trabajos de Jiř́i Levý], en: Jana Králová (ed.), AUC Philologica 2, Translatologica Pragensia X, pp. 155-162; 3) "La traducción de la literatura española en la voz de sus Protagonistas", en: Iberoamericana Pragensia XLVI-1, pp. 97-102. Además, participó en el coloquio "La traducción monacal en el mundo hispánico", celebrado entre el 29 y el 30 de septiembre en Tarazona (Zaragoza), con la ponencia "La traducción monacal desde la óptica de la traductología actual". Durante este año la profesora Králová fue miembro del Tribunal de defensa de la tesis de Elena Serrano Bertos en la Universidad de Alicante.

La PhDr. Anežka Charvátová publicó el estudio “Zábranovy překlady N. Parry: Výchozí text jako zrcadlo překladatelovy duše?" [Las traducciones de N. Parra, realizadas por Zábrana: ¿El texto original como el espejo del alma del traductor?], en: Eva Kalivodová, Petr Eliáš (eds.), Jan Zábrana: básník, překladatel, čtenář [Jan Zábrana: el poeta, el traductor, el lector], Praha: Editorial Karolinum, pp. 74-83. También publicó la entrevista "Překladatel vs. novotvary 1:0" [El traductor contra los neologismos 1:0], en: Martin Kavka, Michal Škrabal a kol., Hacknutá čeština 2.0. Neortodoxní slovník dnešní mateřštiny [El checo hackeado 2.0. Un diccionario no ortodoxo de la lengua materna actual], Brno: Jan Melvil publishing, pp. 199-202.
En la revista mensual literaria Host publicó las siguientes columnas: 1) "Pře" [Disputa], en: Host 2, p. 42; 2) "Veslování ve slovech" [Remando en las palabras], en: Host 4, p. 87; 3) "Tokozelka nadmutá" [El jacinto de agua], en: Host 6, p. 33; 4) "Očima dobyvatelů" [Por los ojos de los conquistadores], en Host 8, p. 75; 5) "Exkluzivní inkluze" [La inclusión exclusiva], en: Host 10, p. 92. En cuanto a las traducciones literarias, en 2018 tradujo del francés a Danny Laferrière y su obra L'odeur du café, como Vůně kávy, Praha: Argo; y del italiano a J. Rodolfo Wilcock y su libro $L a$ Sinagoga degli iconoclasti, como Synagoga ikonoklastů, Praha: Rubato. Dentro de sus actividades de promoción y difusión de la literatura hispanoamericana en la República Checa destacaron sus colaboraciones con la Embajada de México en la República Checa (organización y moderación de la conferencia dedicada a Sergio Pitol "Las huellas praguenses de Sergio Pitol" celebrada el 26 de noviembre); con la redacción de Český rozhlas [Radio checa] Vltava (por ejemplo las emisiones "Reflexe-Literatura" [Reflexión-Literatura] sobre Saramago del 16 de mayo, "Knižní pól" [El polo de libros] sobre los libros importantes del 2 de mayo o "Vizitka" [La tarjeta de visita] sobre Colombia del 7 de mayo); con la estación de Radio checa Plus; con la emisión española Radio Praga; con el Instituto Cervantes de Praga (la tertulia celebrada el 3 de abril con el escritor venezolano Rodrigo Blanco Calderón y el traductor Vít Kazmar sobre la traducción checa del libro Kniha noci [The Night], Praha: Odeon); y con Svět knihy [El mundo del libro] (El foro de traductores y la tertulia con Dolores Redondo celebrados el día 11 de mayo). También participó como presidenta del tribunal en el concurso de traductores principiantes Cena Jiřího Levého [Premio Jiří Levý], organizado por Obec překladatelů; asimismo evaluó las traducciones participantes en el concurso de traducciones elaboradas por estudiantes de institutos "Ars poetica”. La doctora Charvátová además dio varias 
ponencias tanto en la República Checa como en el extranjero. En el simposio "Cien años de relaciones entre Checoslovaquia/República Checa y el mundo hispánico/lusobrasileño" llevado a cabo por el Centro de Estudios Ibero-Americanos, participó con la ponencia "Traducciones al checo de la literatura colombiana y cubana antes y después del 1989". Durante su estancia en Colombia (del 16 al 21 de abril) estuvo presente en Cartagena en la lectura y debate con Petr Stančík y en la mesa redonda sobre las relaciones entre la obra de F. Kafka y G. García Márquez; participó en la Feria Internacional del libro de Bogotá (FILBO) y dio las siguientes ponencias: 1) "Pragicomedia: un viaje literario por Praga" (Librería Luvina); 2) "Los precursores checos del realismo mágico" (Universidad pedagógica, Bogotá); 3) "Sorpresas de olores y sabores de la vieja Praga" (Librería Tango Discos y Libros); 4) "La novela policiaca que ataca todos los sentidos" (Librería Wilborada 1047). Durante su estancia en México (del 24 de agosto al 9 de septiembre) dirigió bajo la Universidad de Xalapa un curso-taller semanal "Traducción y Literatura" de la Cátedra Interamericana "Carlos Fuentes"; el curso abarcó los siguientes seminarios: 1) "Traducir a Carlos Fuentes: cambios de estilo desde $L a$ muerte de Artemio Cruz (1962, en checo 1966) pasando por Gringo Viejo (1985, en checo 2005) hasta Vlad (2012, en checo 2014)"; 2) "Los detectives salvajes y 2666 de Roberto Bolaño: La pluralidad de idiolectos"; 3 ) "La literatura nazi en América, Estrella distante, El tercer Reich de Roberto Bolaño: imágenes, metáforas, humor, metaficción"; 4) "Tres tristes tigres (1967, en checo 2016) de Gui1lermo Cabrera Infante: parodia, sátira, juegos de palabras, cubanismos"; 5) "El hablador de Mario Vargas Llosa: la traducción al segundo grado".

La PhDr. Vanda Obdržálková, Ph.D., publicó los siguientes artículos: 1) "Překlady v antologii Moderní anglická poezie" [Las traducciones en la antología La poesía inglesa moderna], en: Eva Kalivodová, Petr Eliáš (eds.), Jan Zábrana: básník, překladatel, čtenář [Jan Zábrana: el poeta, el traductor, el lector], Praha: Editorial Karolinum, pp. 181-193; 2) "Directionality in Translation: Qualitative Aspects of Translation From and into English as a Non-Mother Tongue", en: Sendebar 29, pp. 35-57; 3) “Terminologická a textová kompetence $\mathrm{v}$ právním překladu: studie na francouzsko-českém materiálu"'[La competencia terminológica y textual en la traducción jurídica: un estudio basado en el material francés-checo], en: Studie z aplikované lingvistiky 1, pp. 73-91; 4) "K narozeninám docentky Zuzany Jettmarové” [Al cumpleaños de la profesora adjunta Zuzana Jettmarová], en: Jana Králová (ed.), AUC Philologica 2, Translatologica Pragensia X, pp. 165-167. La doctora Obdržálková junto con doc. PhDr. Tomáš Duběda Ph.D. y PhDr. David Mraček, Ph.D., fungió como editora de la monografía Překlad do nemateřského jazyka: fakta, otázky, perspektivy [La traducción al idioma extranjero: los hechos, las preguntas, las perspectivas], Praha: Editorial Karolinum.

La PhDr. Mgr. Petra Mračková Vavroušová, Ph.D., publicó el artículo "Soudobá recepce díla Jiř́ho Levého ve Španělsku a Iberoamerice" [La recepción contemporánea de la obra de Jiří Levý en España e Iberoamérica], en: Jana Králová (ed.), AUC Philologica 2, Translatologica Pragensia X, Praha: Editorial Karolinum, pp. 143-153. En lo que se refiere a los congresos, participó como ponente en Pan Vorel mluví španělsky, la presentación de la traducción de los Cuentos de Malá Strana al español, celebrada el 16 de enero en la Universidad Carolina, con la charla "El señor Vorel habla español, o sea, los Cuentos de Malá Strana de Jan Neruda en las traducciones españolas"; luego en Jazyk sousedi, la presentación que formó parte de la estrategia DRESDEN-concept, celebrada el 23 de abril en la Universidad Carolina, con la ponencia "Němčina jako zprostředkující jazyk při překladu české literatury do španělštiny" [El papel mediador del alemán en la traducción literaria del checo al español]; luego junto con PhDr. David Mraček, Ph.D., en la conferencia Translation, Interpreting and Culture: Old Dogmas, New Approaches (?), celebrada entre el 26 y el 28 de septiembre en Nitra (Eslovaquia), con la comunicación "Reflective diaries: developing self-reflection skills in interpreter trainees"; y por último, en el congreso Germanistik in der Mitte Europas - Slowakei, Tschechien, Ungarn, celebrado entre el 18 y el 21 de octubre por DAAD en Bonn (Alemania), con la ponencia "Projektunterricht im Übersetzungsseminaren: am deutsch-tschechischen Beispiel". Además, asistió al seminario Training of Interpreter Trainers (ToT) Workshop on Speech making, organizado por el consorcio EMCI en la Universidad de Budapest entre el 8 y el 9 de febrero. También asistió a las presentaciones dedicadas al tema de la interpretación y organizadas en febrero en la Universidad Masaryk de Brno y en noviembre en la Universidad de Leipzig. Además, la doctora Petra Mračková Vavroušová formó parte del equipo que organizó el seminario 
doctoral Cesty translatologie, celebrado entre el 22 y el 23 de noviembre. El seminario fue organizado por el Instituto de Traductología de la Facultad de Filosofía y Letras de la Universidad Carolina junto con el Círculo de Filólogos Modernos (KMF) y la Dirección General de Traducción (DGT) con motivo del $55^{\circ}$ aniversario de la creación del programa de interpretación y traducción en Praga.

El Lic. Miguel José Cuenca Drouhard, Ph.D., impartió, junto con otros profesores del Instituto de Traductología, un seminario de formación en interpretación para los trabajadores interculturales de la organización InBáze. Dicho seminario fue realizado como parte del proyecto Zvýšení kompetencí interkulturních pracovníků [La adquisición de las competencias de los trabajadores interculturales] y apoyado por la subvención Programy podpory aktivit integrace cizinců na území hl. m. Prahy pro rok 2018 [Los programas de apoyo a las actividades destinadas a promover la integración de los extranjeros en el territorio de Praga para 2018]. A finales del año, el doctor Miguel Cuenca Drouhard organizó un pequeño coro para cantar algunos villancicos españoles en la fiesta de Navidad celebrada cada año en el Instituto de Traductología. En este coro participaron tanto alumnos checos como alumnos españoles visitantes en el marco del programa Erasmus+.

El Lic. Cristian Cámara Outes publicó el artícu1o "Traducción e historia literaria: La influencia de Matteo Bandello en la conformación de la novela picaresca y la novela corta", en: Antonio Bueno García (ed.), Revelación y traducción en la orden de predicadores, Berlín: Peter Lang, pp. 167-189. También publicó el artículo "La teoría humanista de la traducción y el «hechizo» de lo ajeno. Los casos de Martín de León y Horacio Carochi en la escena de la traducción americana", en: Antonio Bueno García (ed.), Antropología y traducción en la orden de predicadores, Berlín: Peter Lang, pp. 179-199. Participó en el congreso International Congress Transiberica, celebrado entre el 15 y el 18 de noviembre en la Universidad de Varsovia, con la ponencia "Los infortunios de la imitación: La noción de traducción en las Anotaciones a Garcilaso (1580) de Fernando de Herrera" y en el seminario Cesty translatologie, celebrado entre el 22 y el 23 de noviembre en la Universidad Carolina, con la ponencia "The Notion of Pseudotranslation in Yuri Tynianov and Jiří Levý”. También publicó su traducción del libro El intervalo y otros ensayos, de Yuri Tyniánov, Madrid: Ediciones Asimétricas; y del libro Arte y producción, de Borís Arvátov, Madrid: Ediciones Asimétricas. En el mes de agosto el Lic. Cristian Cámara Outes disfrutó de una beca concedida por la Casa del Traductor de Tarazona (España), para trabajar en la traducción de una antología de textos teóricos de El Lisitski. Junto con Mgr. Jana Mrkvová, participó en el programa del České Centrum de subtitulado de películas checas. También fungió activamente como integrante del grupo Luces de Bohemia, dirigido por Elena Buixaderas, para la difusión de la cultura y la literatura española en la República Checa.

La Mgr. Jana Mrkvová participó en la publicación de České teorie prekladu [Teorías checas de la traducción] de Jiří Levý (aceptado para la publicación).

En lo que se refiere a los trabajos de Fin de Grado (TFG), Daniela Šnapková presentó la traducción comentada del ensayo El fantasma Pinochet; Veronika Šímová, de La fauna iberoamericana; Zuzana Dudková, de FANFCTION: Fomento de la escritura creativa a través de las formas de literatura emergentes. Mencionando las memorias de licenciatura (TFM), Martina Cimflová concluyó Role přkladatelů a tlumočníků při dobývání Latinské Ameriky [El papel de los traductores e intérpretes en la conquista de América Latina].

Terminando con el programa Erasmus+, seis alumnos de la sección de español pudieron realizar una estancia académica de larga duración en distintas universidades españolas, acogiéndose a las becas de este programa. Del mismo modo, doce alumnos de diferentes universidades españolas realizaron su estancia Erasmus+ en el Instituto de Traductología de la Facultad de Filosofía y Letras de la Universidad Carolina. Dichos alumnos asistieron a las clases impartidas, entre otros, por el Lic. Miguel Cuenca Drouhard, Ph.D.

Finalmente, el 16 de enero fue entregada la medalla de la Facultad de Filosofía y Letras al Profesor Miguel Ángel Vega Cernuda de la Universidad de Alicante por su colaboración con el Instituto de Traductología. En 2018 se presentó también la nueva versión de Povídky malostranské [Cuentos de Malá Strana] de Jan Neruda, realizada por M. A. Vega y el difunto alumno de Doctorado en Traductología Antonio Rivas.

por Zuzana Balounová y Martina Kutková (Escrito en español por las autoras)

https://doi.org/10.14712/24647063.2020.14 